\title{
PERLINDUNGAN HUKUM BAGI HOKI CLEAN SHOES DALAM PERJANJIAN WARALABA
}

\author{
Dwi Purnawan Dodik Saputra, Johannes Ibrahim Kosasih, Desak Gde Dwi Arini \\ Fakultas Hukum, Universitas Warmadewa, Denpasar-Bali, Indonesia \\ dodiksaputra033@gmailcom, johannesibrahim@rocketmailcom, arinidesak1966@gmailcom
}

\begin{abstract}
Abstrak
Bisnis waralaba merupakan salah satu kegiatan bisnis yang menunjang perekonomian. Oleha karena itu, dalam penelitian ini menganalisis tentang pelaksanaan pada klausula-klausula perjanjian waralaba antara pewaralaba dan terwaralaba dan mengetahui perlindungan hukum bagi Hoki Clean Shoes apabila terjadinya wanprestasi yang dilakukan pihak franchisee. Penelitian ini menggunakan metode empiris dengan menggunakan studi dokumen dan studi lapangan dan analisis data dengan menggunakan deskriptif kualitatif. Hasil penelitian menunjukkan bahwa perjanjian waralaba Hoki Clean Shoes telah memenuhi klausula minimum yang harus ada dalam perjanjian waralaba sebagaimana diatur dalam Peraturan Pemerintah Nomor 42 tahun 2007 tentang Waralaba dan telah memenuhi asas-asas perjanjian dan berlaku di Indonesia. Hambatan yang dihadapi Hoki Clean Shoes selama ini adalah berhubungan dengan franchise karena ini di bidang jasa jadi omset yang didapatkan oleh pihak franchise setiap bulannya susah untuk kami ketahui karna manajemen keuangan yang kami lakukan berbeda dengan fakta dilapangan Perjanjian kerjasama waralaba seperti ini juga rentan dengan terjadinya wanprestasi.
\end{abstract}

Kata kunci: perlindungan hukum, perjanjian waralaba franchisee

\begin{abstract}
Franchising is one of the business activities that support the economy. Therefore, in this study, this study analyzes the implementation of the franchise agreement clauses between franchisees and franchisees and knows the legal protection for Hockey Clean Shoes in case of default by the franchisee. This research uses empirical methods using document studies and field studies and data analysis using descriptive qualitative. The results show that the Hoki Clean Shoes franchise agreement has met the minimum clauses that must exist in the franchise agreement as stipulated in Government Regulation Number 42 of 2007 concerning Franchising and has fulfilled the principles of the agreement and is applicable in Indonesia. The obstacles faced by Hockey Clean Shoes so far are related to franchises because this is in the service sector so the turnover obtained by the franchisee every month is difficult for us to know because the financial management we do is different from the facts in the field. Franchise cooperation agreements like this are also vulnerable to default.
\end{abstract}

Keywords: legal protection, franchisee, franchise agreement

\section{PENDAHULUAN}

Pembangunan adalah sebuah proses yang melibatkan berbagai lini kehidupan masyarakat. Proses pembangunan terjadi pada berbagai bidang yaitu di sisi ekonomi politik hukum sosial dan bidang lainnya. Pembangunan yang tepat dan terarah akan membawa kesejahteraan dan kemakmuran bagi masyarakat. Pembangunan dikatakan berhasil apabila tidak menyebabkan terjadinya kesenjangan antar masyarakat. Pembangunan ekonomi merupakan salah satu bidang pembangunan dalam menunjang kehidupan bernegara dan berbanga.

Pembangunan ekonomi diatur dalam Undang-Undang Dasar 1945 Amandemen keempat Pasal 33 ayat (1) (2) dan (3) menentukan: Ayat (1) perekonomian disusun sebagai usaha bersama berdasarkan asas kekeluargaan. Ayat (2): cabang-cabang produksi yang penting bagi negara dan menguasai hajat hidup orang banyak mesti dikuasai oleh Negara. Ayat (3): menyatakan bumi air dan kekayaan alam yang terkandung di dalamnya dikuasai oleh negara dan dipergunakan sebesar-besar untuk kemakmuran rakyat. Ayat (4): perekonomian nasional diselenggarakan berdasarkan atas demokrasi ekonomi dengan prinsip kebersamaan. Ayat (5): ketentuan lebih lanjut mengenai pelaksanaan pasal ini diatur dalam undang-undang.

Dalam hal ini, bisnis waralaba adalah salah satu kegiatan bisnis yang mendukung perekonomian. Isaac Singer adalah orang pertama yang memperkenalkan bisnis waralaba di Amerika Serikat pada tahun 1851 sekitar 1 abad yang lalu ketika perusahaan mesin jahit penyanyi mulai memperkenalkan 
konsep tersebut sebagai cara untuk mengembangkan distribusi produk-produknya di Indonesia. Bisnis waralaba adalah kegiatan bisnis menjual barang eceran ke masyarakat luas. Kegiatan bisnis ini sangat populer sehingga berkembang pesat dan mencakup berbagai jenis bidang bisnis. Pada tahun 1950 bisnis waralaba masuk ke Indonesia dengan munculnya dealer kendaraan bermotor melalui pembelian secara lisensi Tahun 1970 sistem waralaba mulai meningkat dengan berkembangnya pembelian lisensi plus dimana pemilik waralaba bukan hanya sebagai distributor tetapi juga memiliki hak untuk memproduksi produknya. Dalam upaya memberikan perlindungan demi lancarnya proses pembelian lisensi dalam bisnis waralaba maka pemerintah telah mengeluarkan berbagai regulasi dan kebijakan yang mengatur mengenai praktek waralaba dalam hukum dagang. Berbagai peraturan ini dibuat untuk menghindari terjadinya permasalahan di masa mendatang. Berikut ini adalah peraturan yang mengatur mengenai bisnis waralaba di Indonesia:

- Keputusan Menteri Perindustrian dan Perdagangan RI No. 259/MPP/KEP/7/1997 Tanggal 30 Juli 1997 tentang Ketentuan Tata Cara Pelaksanaan Pendaftaran Usaha Waralaba

- Peraturan Menteri Perindustrian dan Perdagangan RI No 31/M- DAG/PER/8/2008 tentang Penyelenggaraan Waralaba.

- Undang-undang No 14 Tahun 2001 tentang Paten.

- Undang-undang No 15 Tahun 2001 tentang Merek.

- Undang-undang No 30 Tahun 2000 tentang Rahasia Dagang

Bisnis waralaba di Indonesia berkembang dengan pesat, maka berbagai peraturan yang telah dibuat oleh pemerintah supaya bisnis waralaba memberikan dampak positif bagi perekonomian dan membawa perkembangan baru bagi bagi dunia usaha. Bisnis waralaba akan memberikan dampak besar bagi industri perdagangan modern. Para pelaku usaha dapat memanfaatkan waralaba untuk memulai usahanya, Pengusaha akan mendapatkan keuntungan dan manfaat dari bisnis waralaba. Popularitas usaha waralaba akan membantu pewaralaba untuk mencapai keuntungan yang lebih maksimal.

Perserikatan waralaba adalah perjanjian khusus karena tidak ditemukan dalam Hukum Perdata Kode Sipil) (Fuady, 1999). Perjanjian ini dapat diterima secara hukum karena dalam KUH Perdata ditemukan. Namun, sistem dalam Buku III KUHPerdata menganut sistem terbuka sehingga dapat memfasilitasi kebutuhan masyarakat. Salah satu pasal yang mendukung implementasi dimaksud adalah adanya kebebasan kontrak. Pasal 1338 (1) KUHP menentukan sahnya atas perjanjian yang telah dibuat antara pihak bagi itu pewaralaba ataupun terwaralaba menjadi suatu Undang-Undang yang sah dan memiliki kekuatan secara hukum. Menurut Meilani \& Witasari (2019) bahwa perjanjian-perjanjian itu penting dan tentunya dilakukan dalam suatu kontrak atau kerja sama antara satu pihak dengan pihak lain, baik perjanjian tertulis maupun tidak tertulis. Begitu halnya dengan usaha waralaba yang diselenggarakan berdasarkan perjanjian tertulis yang memuat kumpulan persyaratan, ketentuan, dan komitmen yang dibuat dan disepakati oleh pihak franchisor dan pihak franchisee (Rahmadany \& Tjukup, 2013).

Perjanjian waralaba merupakan salah satu aspek perlindungan hukum kepada para pihak dari perbuatan merugikan pihak lain (Hanim, 2011). Dalam perjanjian waralaba memuat hak dan kewajiban yang harus dipenuhi oleh para pihak, baik pihak pewaralaba maupun yang terwaralaba. Segala hak dan kewajiban yang telah disepakati harus dipenuhi. Hak dan kewajiban tersebut dituangkan dalam pasalpasal yang telah tertuang dalam perjanjian (Sumardi, 1995). Dalam perjanjian tersebut secara harfiah telah memiliki kekuatan hukum yang kuat dan mengikat para pihak Artinya ketika terjadi penyimpangan maka para pihak yang melakukan pelanggaran dapat dikenai sanksi sesuai yang telah disepakati sebelumnya dalam perjanjian Selain itu adanya perjanjian yang telah disetujui dan ditandatangani oleh kedua pihak juga dapat meminimalisasi terjadinya wanprestasi.

Terjadinya penyimpangan atas kewajiban yang tercantum dalam perjanjian adalah awal yang memunculkan wanprestasi. Hal ini tentunya akan membawa dampak yang kurang baik dan menimbulkan terjadinya pelanggaran atas hal yang telah disepakati. Terlebih lagi, pelanggaran wanprestasi dalam bisnis waralaba telah diatur dalam Peraturan Pemerintah Republik Indonesia Nomor 42 Tahun 2007 tentang Waralaba dan Keputusan Menteri Perindustrian dan Perdagangan Republik Indonesia Nomor 259 / MPP / Kep / 7/1997 tanggal 30 Juli 1997 tentang Ketentuan dan Tata Cara Pelaksanaan Pendaftaran Usaha Waralaba dan Peraturan Menteri Perindustrian dan Perdagangan Republik Indonesia No31 / M-DAG / PER / 8/2008 tentang Waralaba. Selain itu, perlindungan yang dilakukan sebelum penerbitan Peraturan Pemerintah masih digunakan sampai sekarang yaitu Buku III 
KUHPerdata yang mengadopsi sistem terbuka yang berarti memberikan kebebasan kepada setiap orang untuk masuk ke dalam perjanjian yang berisi apa saja asalkan dilakukan tidak bertentangan dengan Hukum ketertiban umum dan moralitas sebagaimana diatur dalam Pasal 1338 ayat (1) KUHPerdata.

Seperti bisnis pada umumnya, kewajiban dalam kontrak waralaba sangat potensial memiliki celah untuk dilanggar atau diabaikan oleh pihak kedua. Dari sudut pandang pemilik waralaba kelalaian dan penipuan waralaba sering terjadi kelalaian membayar barang/royalti setiap bulan dan kelalaian untuk mematuhi sistem yang ditetapkan dalam kontrak waralaba Secara keseluruhan pelanggaran terjadi ketika pemegang waralaba ditemukan tidak mematuhi apa yang telah disepakati.

Sehubungan dengan penjelasan di atas, Hoki Clean Shoes mendapatkan beberapa kasus tersebut pihak kedua selalu mengalami keterlambatan dalam memberikan laporan keuangan secara tertulis kepada pihak pertama. Namun, di sisi lain penipuan yang dilakukan oleh pihak kedua terhadap pihak pertama tidak memesan cairan pembersih sepatu sesuai dengan isi perjanjian waralaba. Shoes Cleaning merupakan salah satu perusahaan yang bergerak di bidang jasa khususnya dalam jasa laundry sepatu. Pelayanan yang dilakukan perusahaan ini mencakupi pencucian sepatu, repaint sepatu, unyellowing sepatu (Yulisar, 2019).

Studi relevan dengan penelitian sekarang telah banyak dilakukan akan tetapi tidak mengkaji rumusan yang sama dengan penelitian ini. Pertama, perlindungan hukum bagi franchise (waralaba) dalam perjanjian bisnis di Indonesia (Supit, 2016). Kedua tentang perlindungan hukum franchisor dan franchisee dalam perjanjian waralaba "soto segeer mbok giyem" Boyolali (Annisa \& Sulistiyono, 2016). Terakhir mengenai perlindungan hukum haki dalam perjanjian waralaba (Adilman \& Santoso, 2010).

Berdasarkan pernyataan di atas, peneliti mencoba menganalisis lebih dalam tentang franchise dari Clean Shoes Hoki yang berbasis di Denpasar-Bali. Dalam perjanjian waralaba antara Clean Shoes Hockey dan franchisee ada beberapa klausa yang telah dilanggar oleh franchisee yaitu keterlambatan dalam memberikan laporan keuangan bulanan dan keterlambatan pembayaran biaya royalti $10 \%$ dari laba (laba bersih) setiap bulan. Tidak hanya itu, franchisee juga secara diam-diam membeli bahan habis pakai (cairan pembersih sepatu) dari distributor lain. Berdasarkan latar belakang di atas, maka penelitian baru ini bertujuan untuk menganalisis penerapan klausul perjanjian waralaba antara pewaralaba dan terwaralaba dan mengetahui erlindungan hukum bagi Hoki Clean Shoes apabila terjadinya wanprestasi yang dilakukan pihak terwaralaba.

\section{METODE PENELITIAN}

Metode yang digunakan dalam penelitian ini adalah hukum empiris Pendekatan masalah dalam penelitian ini menggunakan jenis pendekatan hukum konseptual dan faktual Bahan hukum primer dan sekunder dijadikan sebagai bahan hukum utama dalam penyelesaian studi empiris yang dilakukan Studi dokumen dan studi lapangan adalah cara pengumpulan data yang dipilih untuk menjawab permasalahan yang ada Data yang telah dikumpulkan diselesaikan secara kualitatif berdasarkan hasil wawancara dan penelitian lapangan Data tersebut kemudian disajikan secara deskriptif yaitu dalam bentuk kata-kata tertulis atau lisan dari informan yang berkaitan dengan masalah yang dibahas sehingga kesimpulan dapat diambil.

\section{HASIL DAN PEMBAHASAN}

\section{Pelaksanaan Klausula-Klausula Perjanjian Waralaba antara Pewaralaba dan Terwaralaba}

Implementasi bisnis waralaba berdasarkan perjanjian waralaba harus dibuat secara tertulis antara pemilik waralaba dan pemilik waralaba sesuai dengan Peraturan Pemerintah No 42/2007 tentang Waralaba (Naihasy, 2010). Perjanjian waralaba berisi kewajiban dan hak para pihak termasuk penyelesaian hukum yang dapat dilakukan oleh pemegang waralaba jika pemilik waralaba sebagai pemilik bisnis melakukan wanprestasi. Dalam hukum perjanjian berlaku prinsip yang disebut prinsip konsensualisme. Kata- kata ini berasal dari konsensus Latin yang berarti setuju. Prinsip konsensualisme bukan berarti bahwa suatu perjanjian memerlukan suatu persetujuan. Perjanjian juga disebut perjanjian yang berarti bahwa dua pihak telah menyetujui atau menyepakati sesuatu. Prinsip konsensualisme dapat dilihat dari kondisi pertama dalam Pasal 1320 KUHPerdata (Subekti, 2003). Untuk validitas perjanjian tersebut ada empat persyaratan yang diperlukan, yakni:

a. Sepakat mereka yang mengikatkan dirinya

b. Kecakapan untuk membuat suatu perikatan 
c. Suatu hal tertentu

d. Suatu sebab yang halal

Suatu perjanjian dibuat haruslah berdasarkan kesepakatan para pihak (Komariah, 2009). Perjanjian waralaba yang dibuat didasarkan pada pemahaman dan juga pengertian dari para pihak yang ada. Perlu diketahui bahwa tidak ada perjanjian yang dapat memenuhi keinginan para pihak seratus persen. Perjanjian yang baik adalah perjanjian yang dapat memenuhi dan mewakili kepentingan para pihak tanpa merugikan salah satu pihak. Dengan kata lain, perjanjian yang baik adalah perjanjian yang tidak berat sebelah. Hal ini dilakukan untuk menghindari terjadinya konflik antar para pihak di kemudian hari.

Pemerintah Indonesia telah mengeluarkan beberapa untuk kelancaran roda perekonomian khususnya mengenai bisnis waralaba. Meskipun demikian, para pihak harusnya lebih teliti dan lebih hati-hati dalam menandatangani usaha yang ada. Para pihak tidak boleh melanggar aturan yang telah dibuat karena aturan itu telah didasarkan pada regulasi yang dibuat oleh Pemerintah dan memiliki payung hukum yang jelas. Tidak ada jalan yang lebih baik selain memahami dan mematuhi aturan yang ada dengan jelas. Bagi pihak yang pewaralaba ataupun pihak yang terwaralaba sebaiknya menyatukan persepsi atau dengan kata lain memiliki persepsi yang sama.

Bisnis waralaba adalah bisnis modern yang sedang berkembang pesat di berbagai belahan dunia termasuk di Indonesia. Bisnis waralaba berkembang dengan pesat karena adanya dukungan dari pelaku usaha. Terciptanya iklim usaha yang baik adalah didasarkan pada keterbukaan atas akses informasi yang ada. Suatu usaha akan dapat bertahan dan menjadi kuat dengan didasarkan pada aturan hukum jelas yang mengaturnya. Dalam bisnis waralaba seperti yang telah dijelaskan telah diatur dalam peraturan yang ada. Dengan demikian, jelas bahwa dalam melakukan usaha bisnis akan dapat berjalan dengan baik ketika para pihak mematuhi kewajiban dan hak yang telah disepakati dalam perjanjian yang ada. Intinya adalah bisnis waralaba akan menjadi maju ketika terbangun korelasi usaha yang baik antara pewaralaba atapun pihak terwaralaba. Tidak akan ada hambatan apabila para pihak baik pihak pewaralaba ataupun pihak terwaralaba menyetujui dan menjalankan semua sesuai dengan aturan yang ada.

Bisnis waralaba akan menjadi bisnis yang potensial berkembang, khususnya, pihak-pihak akan sama-sama memperoleh keuntungan apabila mereka menyadari kewajiban dan hak yang ada. Bisnis yang baik adalah bisnis yang berjalan sesuai dengan kaidah-kaidah etika bisnis dan juga tetap berlandaskan pada aturan hukum yang sesuai. Artinya, tidak ada usaha yang tidak berjalan dengan baik ketika kedua hal tersebut telah dilakukan dengan baik oleh para pelaku usaha. Pelaku usaha harus menjalankan usahanya sesuai dengan kaidah dalam peraturan yang ada termasuk dalam bisnis waralaba. Dalam hal ini, Hoki Shoes telah memenuhi segala klausa dan pasal-pasal yang telah sesuai sebagaimana diatur dalam Peraturan Pemerintah No. 42 tahun 2007 tentang Waralaba dan telah memenuhi prinsipprinsip perjanjian dan berlaku di Indonesia. Perjanjian ini terdiri dari 12 Pasal dimana Pasal 1 mengatur mengenai syarat-syarat Pasal 2 mengenai franchise fee dan royalty, Pasal 3 memuat hak dan kewajiban para pihak, Pasal 4 mengatur wilayah usaha, Pasal 5 memuat perubahan system, Pasal 6 mengatur jangka waktu perjanjian, Pasal 7 mengatur laporan, Pasal 8 memuat rahasia dagang, Pasal 9 mengenai wan prestasi, Pasal 10 mengatur pembatalan perjanjian, Pasal 11 mengatur penyelesaian perselisihan dan Pasal 12 membuat bagian penutup.

\section{Perlindungan Hukum bagi Hoki Clean Shoes apabila Terjadi Wanprestasi yang Dilakukan Pihak Franchisee}

Di Indonesia, saat ini, tidak ada undang-undang yang secara spesifik mengatur kontrak bisnis waralaba. Ini dilakukan oleh pemilik waralaba dan pemegang waralaba berdasarkan prinsip kebebasan kontrak sebagaimana diatur dalam pasal 1338 KUH Perdata. Bagi para pihak pewaralaba ataupun terwaralaba sebaiknya memahami atas isi perjanjian yang telah dibuat yang telah dituangkan dalam pasal- pasal ataupun ditulis dalam bentuk klausa-klausa hukum. Dalam perjanjian akan memuat mengenai kewajiban dan juga hak-hak para pihak. Artinya, para pihak dapat memenuhi semua perjanjian yang ada dengan sebaik-baiknya dan menghindari terjadinya wanprestasi. Sebenarnya wanprestasi itu muncul karena terjadinya beda tafsir antara para pihak dengan isi perjanjian yang dituangkan dalam pasal-pasal atau klausa yang telah disepakati. Pemahaman akan pasal-pasal yang termuat dalam perjanjian sebenarnya menjadi kunci utama untuk menghindari konflik antar para pihak. 
Dalam hukum dagang, terjadinya penyimpangan atas perjanjian dikenal dengan istilah wanprestasi. Terjadinya wanprestasi dalam perjanjian waralaba Hoki Clean Shoes yaitu adanya franchisee yang tidak menjalankan atau mematuhi isi dari perjanjian yang awalnya telah mereka sepakati. Pelanggaran yang dilakukan oleh franchise Hoki Clean Shoes adalah franchise yang dimiliki oleh Anak Agung Ngurah Yadnya Wirya Rahmadi Putra (Gung Wah Anyo) yang berlokasi di Jl Bukit Tunggal Nomor 18 Denpasar Barat Denpasar. Sedangkan, Gung Wah Anyo tidak memenuhi kewajiban dalam perjanjian dimana pemegang waralaba tidak membeli 1500000 barang habis pakai standarnya tidak dilakukan karena pemegang waralaba membeli barang habis pakai (sabun pembersih sepatu) di tempat lain. Pemilik waralaba tidak melaporkan hasil keuangan kepada pemilik waralaba setiap bulan. Setelah mendapat teguran 3 kali dari pemilik waralaba maka waralaba melaporkan secara finansial setiap bulan yang kami terima setiap 6 bulan, sehingga tindakan itu melanggar Pasal yang tercantum dalam perjanjian waralaba Hoki Clean Shoes

\section{SIMPULAN DAN SARAN}

\section{Simpulan}

Hasil analisis menemukan jawaban atas permasalahan yang telah diuraikan sebelumnya dan ditarik kesimpulan sebagai berikut: 1) Perjanjian yang dibuat Holi Clean Shoes sesuai dengan pasal-pasal yang harusnya dimuat dalam perjanjian waralaba dan sesuai dengan Peraturan Pemerintah Nomor 42 tahun 2007 tentang Waralaba dan telah memenuhi asas-asas perjanjian dan berlaku di Indonesia. Perjanjian ini terdiri dari 12 Pasal dimana Pasal 1 mengatur mengenai syarat-syarat Pasal 2 mengenai franchise fee dan royalty, Pasal 3 memuat hak dan kewajiban para pihak, Pasal 4 mengatur wilayah usaha, Pasal 5 memuat perubahan system, Pasal 6 mengatur jangka waktu perjanjian, Pasal 7 mengatur laporan, Pasal 8 memuat rahasia dagang, Pasal 9 mengenai wan prestasi, Pasal 10 mengatur pembatalan perjanjian, Pasal 11 mengatur penyelesaian perselisihan dan Pasal 12 membuat bagian penutup.

Kemudian, 2) Perlindungan hukum bagi hoki clean shoes apabila terjadinya wanprestasi yang dilakukan pihak franchisee Praktek kontrak bisnis franchise tertulis kontrak kerja sama Dalam perjanjian yang dibuat dengan sistem kontrak kerja harus berdasarkan sistem kehati-hatian dan harus teliti dengan apa yang tertulis dalam kontrak Dalam perjian yang dibuat Hoki Clens Shoes terkait dengan hambatan dalam pelaksanaan perjanjian diatur di Pasal 11 dimana apabila terjadi wanprestasi maka pihak-pihak yang ada dalam perjanjian akan menyelesaikannya dengan musyawarah mufakat Apabila pemrasalahannya semakin tajam dan tidak bisa diselesaikan dengan baik-baik maka penyelesaiannya dapat melalui jalur hukum di pengadilan.

\section{Saran}

Melalui penelitian ini diharapkan kepada pemerintah untuk segera membuat peraturan yang lebih pasti dan melakukan pembenahan terhadap peraturan-peraturan yang ada Hal ini untuk menghindari terjadinya kesalahan-kesalahan yang dapat merupakan salah satu pihak atau para pihak yang terlibat dalam bisnis waralaba Artinya setiap pihak yang terlibat memiliki payung hukum yang jelas Adapun yang dapat dilakukan adalah dengan memperjelas aturan dan juga regulasi yang ada Dengan jelasnya aturan dan regulasi yang mengatur tentang bisnis waralaba maka baik bagi pihak pewaralaba maupun pihak yang terwaralaba dapat lebih merasa aman secara hukum dan bisnis yang dijalankan juga akan menjadi lebih berkembang.

Selain itu, diharapkan kepada para pihak baik pihak pewaralaba maupun pihak yang terwaralaba, sebaiknya, hati-hati dalam menuangkan pasal-pasal atau klausa-klausa yang ada dalam perjanjian. Artinya, para pihak sebaiknya lebih memperhatikan sebelum menyetujui dan menandatangani perjanjian yang dibuat Suatu perjanjian akan menjadi kuat dimata hukum setelah para pihak setuju dan tanda tangan. Jadi, sebelum perjanjian disepakati sebaiknya para pihak benar-benar paham dan mengerti dengan isi klausa-klausa yang ditulis. Hal ini dilakukan untuk menghindari terjadinya wanprestasi yang mungkin dapat terjadi kedepannya yang dilakukan oleh para pihak baik itu pewaralaba ataupun terwaralaba akibat salah pengertian dengan klausa yang ada.

\section{DAFTAR PUSTAKA}

Adilman, A., \& Santoso, B. (2010). Perlindungan Hukum HAKI dalam Perjanjian Waralaba (Universitas Diponegoro Semarang).

Annisa, R. N., \& Sulistiyono, A. (2016). Perlindungan Hukum Franchisor dan Franchisee dalam Perjanjian Waralaba "Soto Segeer Mbok Giyem" Boyolali. Privat Law, IV(01), 95. 
Fuady, M. (1999). Hukum Kontrak dari Sudut Pandang Hukum Bisnis. Bandung: PT. Citra Aditya Bakti.

Hanim, L. (2011). Perlindungan Hukum HAKI dalam Perjanjian Waralaba di Indonesia. Jurnal Hukum Fakultas Hukum Unisula, 2, 571-589.

Komariah. (2009). Hukum Perdata. Malang: Universitas Muhammadiyah.

Meilani, S. P. I., \& Witasari, A. (2019). The Legal Protection Of Workers' Rights Fulfillment of the Homeworker in the Industrial Relations Court Semarang. Jurnal Daulat Hukum, 2(2), 231-238.

Naihasy, S. (2010). Hukum Bisnis (Business Law). Yogyakarta: Mida Pustaka.

Rahmadany, T. F., \& Tjukup, I. K. (2013). Perlindungan Hukum bagi Franchisee Terkait Pendirian Usaha di Bidang yang Serupa Setelah Berakhirnya Perjanjian Waralaba. Kertha Semaya: Journal Ilmu Hukum, 01(09), 1-13.

Subekti, R. (2003). Hukum Perjanjian. Jakarta: Citra Aditya Bakti.

Sumardi, J. (1995). Aspek-Aspek Hukum Franchise Perusahaan Transnasional.

Supit, I. (2016). Perlindungan Hukum Bagi Franchise (Waralaba) Dalam Perjanjian Bisnis Di Indonesia. Lex Administratum, IV(4), 92-100.

Yulisar, A. A. (2019). Sistem Informasi Pelayanan Jasa Laundry Sepatu pada Shoes Cleaning Majalengka (Universitas Komputer Indonesi). 